\title{
READY FOR CHANGE? INTERLINKAGES OF TRADITIONAL AND NOVEL PRACTICES THROUGH PERMACULTURE
}

\author{
Elgars Felcis ${ }^{1}$, Scientific Assistant / MA; Weronika Felcis ${ }^{2}$, Scientific Assistant / MA
}

1, 2 University of Latvia, Advanced Social and Political Research Institute

\begin{abstract}
This paper is based on ongoing participatory action research in Latvia since 2016. The research was initially developed within the Marie Curie Innovative Training Network SUSPLACE and is further advanced by the Latvian Council of Science funded project 'Ready for change? Sustainable management of common natural resources (RFC)'. By using this approach, the researchers aim to, firstly, synthesise natural, climate science and economic systems evidence of the immense transformations required towards regeneration and, secondly, engage in active knowledge brokerage and societal change advancement. Authors encourage to limit the application of the abused term 'sustainable' as it has rather meant to 'sustain the unsustainable' across the last decades and to follow the logic of 'regeneration' instead.

The bridging of practices with the permaculture movement can be summarised in three broad groups of regenerative transformations to develop resilience against environmental breakdown - firstly, organic growing or gardening, secondly, ecological building, and thirdly, ecological lifestyle practices. These examples are arising both from particular collaborations with the selected permaculture homesteads as well as from the general environmental and social activism in Latvia.
\end{abstract}

A common expression claims that 'everything new is well forgotten old'. It resonates very well with the permaculture ethics and movement emphasising not forgetting yet critically assessing the long-developed skills and practices. This paper demonstrates that in addition to the challenging global aims, on the local level the success of permaculture depends on its ability to be deeply embedded in localities and revive cultural, local practices that people feel a connection to.

Key words: permaculture, regenerative transformations, environmental breakdown, degrowth.

JEL code: Q5 Environmental Economics

\section{Introduction}

'When long-established systems break down, they often do so in many different ways at the same time. Our economy and society depend on a lot of things working right, all the time: cheap and reliable flows of energy, a stable climate, fertile soils, abundant fresh water, productive oceans, an intact, diverse ecology, high levels of employment and a cohesive culture. These are all in trouble.' (Fleming, 2016: 3)

The first year in the Covid-19 pandemic is a catalyst for the breakdown of our long-established systems (Spash, 2020). The research team had posed the questions about the awareness of change and readiness for change already in 2019 application for the currently implemented research project RFC. The change we meant was primarily about the societal response to the ongoing environmental breakdown. Pandemic is just another milestone on this path, partially driven by the human encroachment of the natural world and increased spread of zoonotic diseases (Sansonetti, 2020).

We live in an era of environmental breakdown that is a direct outcome of the modern scientific and technological process - side-effects of our development (Beck, 2009). Interdisciplinary research is showing how these side-effects are manifesting in many aspects of human societies. Critique and evidence have been provided already since the mid-20 $0^{\text {th }}$ Century with influential books like 'The Great Transformation' (Polanyi, 1944), 'Limits to Growth' (Meadows et al., 1972) and 'Small is Beautiful' (Schumacher, 1973), each different in their approach but all strongly emphasizing the incompatibility of infinite growth with prosperous long-term development.

Since those early sustainability-oriented authors and movements more work has followed in describing fundamental flaws for long-term sustainability, but almost none of the negative trends exceeding planetary

1 elgars.felcis@lu.Iv 
boundaries (Steffen et al., 2015a) have been reversed and instead, the problems have only expanded (Steffen et al., 2015b, Ceballos et al., 2017, Bendell, 2018, IPCC, 2018, IPCC, 2019, IPBES, 2019, Dasgupta, 2021). Human progress side-effects cannot be solved while remaining in the same hegemonic paradigm of progress, modernity and development based on neo-classical economics, neoliberal capitalism, free market, the panacea of technological solutions, and infinite growth. There are almost no countries in the world, where GDP growth would not be among the primary country development target indicators. Widely popularised alternatives like 'Green economy' and 'Green growth' introduce some changes, but are not challenging the essential aspects of such hegemony (Spash, 2012) and are not decoupling economic growth from environmental degradation (Fletcher \& Rammelt, 2016, Parrique et al., 2019). The problems present at all scales of human societies are interlinked and long-term regeneration can be achieved if development actors will contribute to mindset shifts away from the paradigm hegemony (D'Alisa et al., 2014, Gopel, 2016). The term 'sustainable' likewise is a part of the same paradigm that it is possible to painlessly combine the economic growth aim with social and environmental sustainability. 'Sustainable development' framework is proposed for more than three decades, but the climate change and other socioecological disruptions make redundant the reformist approach to sustainable development and related fields of corporate sustainability that has underpinned the approach of many professionals (Bendell, 2018).

One of the ways in the direction to transcend the paradigm hegemony is the international permaculture movement. The term itself was formulated in the 1970 s by Bill Mollison and David Holmgren (1978). Initially, it was focused on the agricultural aspects as in 'permanent agriculture', however, by the early 1990 s permaculture already has been redefined as '... a design system for creating sustainable human environments. The word itself is a contraction not only of permanent agriculture but also of permanent culture' (Mollison \& Slay, 1991). The core ethics of permaculture are threefold: 'Earth care, people care and fair share' (Holmgren, 2002). That relates closely with the discussion in environmental philosophy and ethics about the risks associated with anthropocentrism leading to ecosystem degradation and resource exploitation (Keller, 2010).

It is essential to see permaculture not as a revolutionary novel approach to farming or living, but as an overall framework that brings together many diverse environmental ideas in a coherent pattern. Permaculture as both philosophical and practical framework is establishing itself as reliable for transformative action (Henfrey, 2018) and part of the success is the ability to bridge the traditional and novel practices, exemplifying hopeful alternatives or 'real utopias' (Wright, 2010) capable of challenging dominant economic paradigms. Many of the practices in permaculture design are aiming for regeneration as indicated in the sub-title 'Principles and pathways beyond sustainability' (Holmgren, 2002) and reappearing throughout the 12 core permaculture principles. Regenerative implies the focus on not generating problems in the first place and regenerating the negative impacts social and economic practices in places have made so far - aiming to leave a better world for future generations (Lyle, 1994). This paper demonstrates the examples of regenerative aspirations and the development of societal alternatives within the permaculture movement in Latvia. Through this, the central research question is explored on how permaculture in Latvia supports regenerative transformations and bridges traditional and novel practices.

\section{Materials and Methods}

'There are two relevant meanings of growth:

1) The natural development of an immature system or organism to maturity.

2) A pathology in which a mature system or organism continues to grow.' (Fleming, 2016: 127) 
This paper is based on ongoing participatory action research in regeneration-oriented initiatives in Latvia beginning in 2016. Essentials for action-oriented, transformations and climate change research, summarized on the basis of individual and collective outputs in a two-year collaboration of almost 50 scientists (Fazey et al., 2018) are reflected in much of our work. The essentials recommended are based on the expressed need for 'massive upscaling of research that can rapidly enhance learning about transformations' with particular focus areas on transformations to low-carbon, resilient living, on 'how to' practical knowledge, seek to transcend current thinking, acknowledge the value of alternative roles of researchers and the scientists conclude that 'the most critical question for climate research is no longer about the problem, but about how to facilitate the transformative changes necessary to avoid catastrophic climate-induced change' (Fazey et al., 2018: 55). Such essentials indicate that research approaches themselves need to undergo fundamental changes if they want to contribute to regenerative transformations.

This research project has a strong emphasis on participatory action research and therefore it is crucial not to fall into the trap of empiricism; the implicit ontology risks confusing the 'empirical' with the 'real' domain. When projects are fundamentally based on the knowledge, needs, and interests of stakeholders, they primarily rely on empirical information provided by project participants. As argued by Sayer (2000), 'Observability may make us more confident about what we think exists, but existence itself is not dependent on it' (p. 12). This can lead to vulnerability of describing the reality within the dominant development paradigms, using the same language, and imagining the same desirable actions based on hegemonic perceptions of development. Meaningful new dimensions in the development of society require a framework like degrowth provides, indicating what 'actual' and 'real' development trends and future risks must be taken into account to design more specific empirical work and stimulate the development of more regenerative transformations at multiple levels of society. These challenges are related to previously described challenges of normativity and ethics in action-oriented research to achieve regenerative transformations, because then research cannot primarily rely on empirical information from participants, but need to relate it to biophysical limits inevitable in regenerative transformations.

The regenerative approach is closely related to the body of work produced in the degrowth tradition, particularly the key book 'Degrowth. A Vocabulary for a new era' (D'Alisa et al., 2014), offers a frame that connects diverse ideas, concepts, and proposals (Demaria et al., 2013) that together frame the impossibility of infinite growth. '[Degrowth] calls for the decolonization of public debate from the idiom of economism and for the abolishment of economic growth as a social objective. Beyond that, degrowth signifies also a desired direction, one in which societies will use fewer natural resources and will organize and live differently than today. 'Sharing', 'simplicity', 'conviviality', 'care' and the 'commons' are primary significations of what this society might look like' (D'Alisa et al., 2014: 3).

However, degrowth has no ambitions to become a one-dimensional ideology and path for everyone to follow. People in the movement understand that its name and core critique originate in the overdeveloped 'Global North', where 'further economic growth [...] no longer improves health, happiness or measures of wellbeing' (Pickett \& Wilkinson, 2009: 172). While in 'Global South' degrowth might be a less appealing term for a movement, other similar movements are emphasising the same qualities and different long-term perspectives from the current global hegemony ('Ubuntu' in South Africa, 'Buen Vivir' in Latin America, or 'Ecoswaraj' in India). Degrowth is largely about building alliances across the world and showing the multiplicity of paths that can be taken to achieve better future societies that are conscious of the limits of global biophysical reality. 'The foundational theses of degrowth are that growth is uneconomic and unjust, that it is ecologically unsustainable, and that it will never be enough. Moreover, growth is likely to be 
coming to an end as it encounters external and internal limits' (D'Alisa et al., 2014: 6). Therefore, the degrowth framework provides an all-rounded complex perspective on the 'actual' and 'real' domains as in the Critical Realism ontology - all of it affects our 'empirical' human perception of the world and actions we are likely to take, regardless of how conscious we are of our actions (Archer et al. 1998, Bhaskar et al., 2010).

An action-oriented approach merging these roles enables an in-depth involvement in the ongoing projects and communities in Latvia that have a regenerative potential to serve as examples for a wider population. In the context of development paradigm critique in this research, it is important to re-politicize action-oriented research and to emphasise 'dialogic engagement with co-researchers, and the development and implementation of context-appropriate strategies oriented towards empowerment and transformation at a variety of scales' (Kindon et al., 2007: 2).

In Central and Eastern Europe and Latvia, there is a strong sense of failure of communism, fragile democracies, people who are often disillusioned and it makes it very difficult to involve people in social movements, especially if they can be linked to communism as is the risk in case of social and environmental justice left-oriented ideas or frameworks beyond right-left political spectrum like permaculture or degrowth.

Therefore, it is a very complex challenge in Latvia for anyone willing to adapt or adjust some of the ideas, language, and practices of global movements towards sustainability or regeneration; for example, permaculture, agroecology, regenerative agriculture, food sovereignty, degrowth, transition towns, all of which are encompassing the types of 'real utopias' that could be worked towards in the settings of Latvia. Such actions risk being labelled as reversing the development trend towards the genuinely difficult times of recent history and therefore discrediting any such attempts. However, through appreciation of old practices and folk traditions as well as strong relation to global movements, social activism, and evidencebased understanding of planetary challenges, the permaculture movement in Latvia is developing itself as one of the guiding frameworks for alternative actions.

This paper provides insights into participatory action research attempts in the particular circumstances of Latvia - researching the ongoing processes and leading or co-creating multiple activities since 2016 :

- 2 internationally recognised Permaculture Design Certificate (PDC) courses in 2017;

- diploma in Applied Permaculture process initiated in 2018 and first Diploma holder graduated in 2020;

- plans for PDC course in Latvian tailored to local needs in 2021;

- 5 annual permaculture festivals with multiple lectures and practical workshops (100-180 people in attendance of each from 2016 to 2020);

- >10 Rocket Mass Heater (RMH) practical workshops;

- 6 successful project applications and implementation;

- >10 national-level radio appearances on permaculture, climate change, and degrowth;

- >10 university guest lectures in four different Latvian universities to students of economics, management, sociology, agriculture, and eco-technologies - about interdisciplinary science, permaculture, degrowth, and participatory action research;

- >10 public lectures in various settings, for example, annual discussion festival LAMPA;

- Elgars Felcis leading the Latvian Permaculture Association (LPA) as its chairman since 2016;

- both authors leading the multifunctional open permaculture homestead 'Zadini' and foundation 'Zadini' since 2018.

Co-created events and activities are providing diverse sources of information and data: 
- photos and video material of events and daily work;

- in-depth insights into the day-to-day operation of permaculture activists and homesteads (including recorded interview and discussion material);

- evaluation material from workshop participants (quantitative and qualitative);

- overall development of in-depth insight about the people interested in permaculture practices and their steps towards regeneration - from multiple workshops, seminars and permaculture festivals.

However, the aim of the participatory action research process is not only to document some of the actions based on people's claims in interviews or discussions but predominantly to contribute to regenerative transformations in the society through the co-creation of activities, events, workshops, and longer-lasting collaborative networks as summarised above.

Moreover, following, observing, and engaging with Latvian permaculture homesteads is useful in this work because of their ongoing practical application of regenerative aspirations. For the research, the most active permaculture homesteads within the broader permaculture movement were selected that demonstrate leadership and ambition to promote simpler and more regenerative lifestyles as individuals and encouraging communities in their network. Summative criteria for selection of such places and their regenerative potential:

1) mature, longer-term functioning places - proven their resilience in organisational hardships beyond the first couple of years of existence;

2) a high degree of autonomy - independence in aims, practices, diversified income streams, and/or a potential to increase self-subsistence;

3) bottom-up - developed in a bottom-up process by individuals, families, or communities;

4) regeneration-oriented - have a high environmental awareness and are aspiring to further increase their regenerative capacity;

5) providing example and inspiration for change - are recognized by wider society and organize events, workshops, and other educational processes for the general public.

In summary, our engaged researchers' roles and alternative roles such as Elgars being the chairman of the LPA leads to in-depth collaboration with the described permaculture farms which involves different combinations of local, regional, and international actions which are merging traditional and novel practices. Firstly, co-organisation of events, facilitating discussions and practical work. Secondly, co-leading actions within the LPA with them as key members of the association. Thirdly, co-writing of project applications and implementation of the projects to foster regenerative activities and use of permaculture principles and practices.

\section{Research results and discussion}

The bridging of practices within the permaculture movement can be summarised in three broad groups of regenerative transformations - firstly, organic growing or gardening, secondly, ecological building, and thirdly, overall ecological lifestyle practices. These examples are arising both from particular collaborations with the selected permaculture homesteads as well as from the general environmental and social activism in Latvia.

The identification with the first group is the most widespread in Latvia - the majority of permaculture enthusiasts admit that they have first come across permaculture in relation to gardening practices and only then have discovered other wider aspects of it. More active early organic farmers in Latvia in the early 2000s have come across permaculture as a set of practices in an experience-exchange trip to Austria, 
but a common attitude among farmers is that permaculture is a suburban practice, but not for consistent food production. Gardening and farming practices emphasised in permaculture focuses on nature and biosphere mimicking - for example, companion planting, natural pest control, agroforestry, and ground covers in different forms or mulching. On the spectrum of alternative farming practices to industrial farming, permaculture lies next to agroecology, organic and biodynamic agriculture that all share several similar features and have influenced each other over time. Even no-till or reduced tillage practices prevalent in the permaculture movement are becoming picked up by the Latvian Organic Farmers Association and other farming groups. Other common land management practices in permaculture - key-line design and holistic management - at the moment have only the first attempts to be adapted to Latvian settings.

Multiple permaculture enthusiasts and organic farmers are attempting to repeat some of the practices of Richard Perkins, a British farmer working on a farm in Sweden (Ridgedale Permaculture) in more Northern latitudes than Latvia. His advice is appealing because of the similar climatic conditions and intensive social media presence and success stories. Latvian Rural Advisory and Training Centre (LLKC) consultant, Latvian permaculture association (LPB) member has organised two Richard Perkins' lectures in Latvia in 2015. Furthermore, his self-published books 'Making Small Farms Work' (2016) and 'Regenerative Agriculture' (2019) are good examples indicating the close links between 'permaculture', 'regenerative agriculture' and other practices in the wider agroecological movement. Within the LLKC there is a growing recognition of permaculture as a part of the alternative spectrum towards regenerative practices and reduction of the risks and side-effects that industrial agriculture is producing.

Secondly, ecological building practices in Latvia have an alive and lasting heritage with log building as a classical feature of Latvian countryside with log building companies and master craftsmen working on them also nowadays (for example, the professionally marketed 'Northmen Guild' and their carpentry and log building courses), often combined with traditional roofing materials - thatched reed roofs and wood shingles. Permaculture activists are keen in cherishing all such heritage, but they do make few additions with straw bale and cordwood building techniques, reciprocal roofs, tiny 'hobbit houses' as well as with the introduction of Rocket Mass Heater wood-burning ovens. The latter was first built in Latvia in 2013 and since then at least 50 such heaters are built, many of them in open workshops where people are invited to participate for free or low cost to help the host build the oven and simultaneously learn the skills themselves. The Facebook group 'RMH in Latvia' ('Rakeskrasns Latvija') since its establishment in late 2017 has expanded to 2400 followers in early 2021. RMH is a good example of a product that is difficult to commercialize regardless of its high burning efficiency, low emissions, low wood consumption, and cheap construction costs, particularly if materials are re-used, upcycled from other sources and the oven is at least partially self-built. For example, the cost of materials for one RMH in Latvian circumstances can be between 200 and $300 €$ in 2021. Because of their features, RMH are appreciated by a wider population, including those not particularly focused on ecology, regenerative practices or permaculture, but strong in self-building and technical skills. Sometimes it serves as the entry point to understanding how the ecological building is a part of a broader lifestyle approach. For example, it is the main reason for some people to attend the annual permaculture festival where they get to know more about the permaculture movement and other practical lifestyle alternatives.

Thirdly, overall lifestyle changes is a more ambitious step, but permaculture proves to be a useful set of guiding ethical and practical principles for environmentally friendly, ecological, sustainable or other similar description people might prefer to use. Furthermore, there are still such people who are not using some or any of such descriptions, but their lifestyles in many ways resemble permaculture framework particularly among the rural population. In essence, that is the role of permaculture - instead of claiming 
to be the new, innovative, or revolutionary way, it rather is a systemic framework to learn from past knowledge and experiences. For example, zero-waste principle is long included as one of 12 permaculture principles (Holmgren 2002), but around it develops a more recent separate movement and development of zero-waste shops in several Latvian cities.

In permaculture, there are useful reminders that higher levels of self-sufficiency and independence is also a political act and contribute to the decentralisation of power socially, politically, economically, and technically. However, it is rarely perceived as such in Latvia, because of self-sufficiency predominantly being related to forced past hardships and underdevelopment (Dzenovska, 2012). For example, climate change perception as an environmental threat in Latvia is among the lowest in the EU. However, among permaculture activists, such awareness of climate change and other aspects of environmental breakdown is much higher, which provides an additional stimulus for actions to consciously adapt to the growing impacts of these breakdowns.

\section{Permaculture homesteads - key nods in the permaculture movement in Latvia}

In the following paragraphs, the permaculture homesteads will be shortly described based on the criteria mentioned in the methods section and then demonstrate how they are operating as key nods in the wider permaculture movement activities in terms of ecological growing, building, and living in Latvia and internationally.

\section{Permaculture homestead 'Lejas Variceni'}

The smallholding is led by a Latvian-German family since 2011 and they are also leading the local NGO 'Smiltenei un Latvijai' ('For Smiltene and Latvia'). During these years they have rapidly developed their homestead, hosted more than 150 voluntary workers and multiple workshops on building RMH stoves, straw bale building techniques, and hosted the third Latvian Permaculture Festival in August 2016. In 2017 they hosted two Permaculture Design Certificate courses (PDC) and co-organised the fourth and fifth Latvian Permaculture Festivals in 2017 and 2018 together with other active LPA members. In 2018 they started co-hosting Diploma in Applied Permaculture process in Latvia in order to train permaculture trainers and spread the movement further nationally and regionally. In 2020 the farm owner defended his 10 applied permaculture project portfolio and became the first Diploma holder in Latvia and the Baltics who can further teach and grant PDC certificates. There are plans for a PDC course first time fully in Latvian in 2021.

To sum up, 'Lejas Variceni' is considered as a place with a regenerative potential because it:

1) Developed continuously since 2011, therefore it has proven its resilience in organisational hardships beyond the first couple of years of existence.

2) Have diversified streams of income and self-subsistence - social work in being a host-family in German 'Wellenbrecher' organisation (until 2020), part-time teaching in a school or private teaching, permaculture farming and animal husbandry, organisation of workshops, occasional EU Cohesion Fund project writing and implementation.

3) Was founded by a family in 2011 after transitioning their lives from corporate employment in Germany through several steps towards the current permaculture homestead management in Latvia.

4) Have regeneration aspirations at the core of their operation - concerning permaculture design principles and expanding understanding of global climate change pressures.

5) Have achieved popularity among people interested in permaculture in Latvia, Estonia, and abroad as well as receiving voluntary workers from all around the world. A key sign of success is the willingness 
of people to return to subsequent workshops and events and frequent mass media interest in various newspapers and TV programs.

\section{Permaculture homestead 'Ganeni'}

The family running the homestead are also the leaders of the NGO 'Kulturys studeja Speiga' ('Kulture study Speiga') that is active in attracting funding for the development of rural communities, involving the local community and presenting advantages of permaculture principles in farming and lifestyle. The homestead and foundation have been the hosts of the first two Latvian Permaculture Festivals in 2014 and 2015, as well as have organised several workshops, for example, 'Build your house yourself' workshop in log house building in May 2016 and 'Make your own roof yourself' workshops of timber frame constructions and wooden roof shingle making and laying every year since 2017.

To sum up, 'Ganeni' is considered as a place with a regenerative potential because it:

1) Developed gradually and demonstrated resilience in adapting to various difficulties throughout the years since 2007.

2) Have diversified streams of income and strong self-subsistence - permaculture farming and animal husbandry, organisation of workshops, regular project implementation for popularisation of environmentally friendly lifestyles and alternative farming practices.

3) Was founded by a family in 2007 as 'back-to-the-landers', soon starting to follow some permaculture principles and aiming to prove that it is possible to live happy lives in the Latgale region country-side that are generally perceived as the least developed territories of Latvia.

4) Have regeneration aspirations at the core of their operation - concerning permaculture design principles and reducing dependency on monetary exchange.

5) Have achieved popularity among people interested in permaculture in Latvia and elsewhere, hosted numerous workshops, volunteers, and works to strengthen the nearest local communities in the Latgale region.

\section{Open homestead 'Zadini'}

'Lejas Variceni' farm owners are close partners and supporters to the emerging 'Open homestead Zadini' ('Atverta Saimnieciba Zadini'). This is a relatively recent development, first conceptualised in 2017 and inhabited by multiple families since 2018. It includes the management of the 90ha property of an AmericanLatvian environmental justice and climate change activist in the USA, who is willing to dedicate her Latvian property to serve as a common pool property ('commons') in supporting young people in Latvia for alternative thinking, growing, building and living practices. The foundation 'Zadini' was established in 2019 with the aim to be the organisation managing the property in the future.

To introduce the project and place, the fourth Latvian Permaculture festival was organised there in August 2017. Furthermore, a Rocket Mass Heater and natural paints workshop was organised in November 2017, another RMH workshop in April 2018, 'Activist burnout academy' in June 2018, part of the 'Diploma in applied permaculture design' course, multiple other smaller events for Latvian and international audiences and the fifth and seventh annual Permaculture festivals in August 2018 and August 2020. The latter two were co-organised with the support from 'Lejas Varicēni' and 'Ganeni' owners, other active Latvian permaculture association members as well as several Latvian environmental organisations and social and environmental activists.

As scientists and activists, the authors have taken the lead in the project, acting as the trusted people between the landowner and people joining the open farm and cooperating with the 'Lejas Varicēni' 
homestead. In early 2021 there are already 12 permanent inhabitants (seven adults and five children) in 'Zadini' and the homestead is open for potential new members.

To sum up, 'Zadini' is considered as a place with a regenerative potential because it:

1) Is in the process of developing and has generated national recognition in the general public and mass media. Furthermore, strong links are established with the local community and school.

2) Have diversified skill-sets of participants (agriculture, forestry, herbalism, mechanic, construction, project management, etc.), multiple streams of personal and collective income, and strong potential for future self-subsistence. Regular weekly meetings are held to steer further development, practices, and projects.

3) Developed by a group of 'back-to-the-landers' willing to change their lifestyles and becoming 'part of a solution' not 'part of the interlinked ecological, social and economic problems'.

4) Environmental and social regeneration aspirations are central, using the multiple skills, permaculture framework, deep ecology, social work, and other inspirations.

5) In the relatively short period since the foundation 'Zadini' inhabitants have already organised multiple events, workshops and hosted many groups from schools, regional NGOs, mass media, and people interested in exploring the experiences or possibilities to join as community members.

The overarching theme that enables the multi-stakeholder involvement is the openness for others to learn what is done in these farms and how the owners can inspire and empower others in the reception of voluntary workers, aspiring back-to-the-landers, permaculture enthusiasts, and journalists. Indeed, since 2016 permaculture-related activities and places increasingly more often appear on local and national radio, TV, and Youtube channel episodes as well as on newspaper and journal articles.

Many of the projects within the LPB are written and implemented by some or all of the above-mentioned farm representatives. Sometimes projects are submitted directly through LPB, but on other occasions through the NGOs that are led by the homestead owners. They together with a wider circle of active LPB members form a very resourceful group trying to secure support for the ideas that advance rural regeneration and social resilience through permaculture practices. One of the keys to their success is the ability to simultaneously be very deeply embedded in the local region with its stakeholder network, but at the same time being different and partially through permaculture bringing in some novelties that in turn becomes appealing for others in the region. Their embeddedness is what makes others to pay attention and appreciate the work they do. For example, like in the 'OFF-GRID' project, when there was a recognition about the need to advance renewable energy sources in Latvian regions and the EU LEADER 'Local Action Group' (LAG) invited and consulted the project application on the novel, sustainability-related issues knowing the interests and expertise of the homestead owners.

\section{Conclusions, proposals, recommendations}

1) In conclusion, our analysis of environmental breakdown evidence emphasizes the need to move beyond the usual paradigms of 'sustainability' or 'sustainable development'. Their track record since 1980ties shows that economic growth and associated resource throughput growth has been prioritised at the cost of social and environmental degradation. The trends are genuinely disturbing. Therefore, the authors propose to follow the logic of the concepts of 'regeneration', 'regenerative transformations', and 'degrowth' as the necessary guiding pathways internationally and in Latvia at the current point in history. 2) This article explains how the permaculture framework aligns with the overall regenerative paradigm while including a diverse range of people in Latvia - from cities, small towns, aspiring 
'back-to-the-landers', people already in rural regions and each group finds some application of different aspects of permaculture. Permaculture fits the rapidly internationally growing rhetoric that unprecedented transformations are necessary as soon as possible to have a liveable Planet Earth.

3) The authors have explored the role and pathways of participatory action research for regenerative transformations. Both the analysed existential risks and such co-creative research methodologies are novel in the Latvian academic community. Hopefully, that will contribute to awareness, readiness, and resilience to ongoing changes and further meaningful research on that. Participatory action research in Latvia demonstrates that in addition to the challenging global aims, on the local level the success of permaculture depends on its ability to be deeply embedded in localities and revive cultural, local practices that people feel a connection to.

4) The aforementioned permaculture practices in gardening/farming, eco-building, and ecological lifestyles demonstrate that regenerative transformations cannot arise only from individual choices, but instead through a larger social change and revived values of commonality. In the Latvian permaculture movement, diverse events are providing practical examples, know-how, and encouraging further changes in their lives and mutual collaboration.

5) Doreen Massey (2005) also has argued that the local continuously constructs the global and people and places are not just victims to global structuring processes but have agency and capacity to act. Even if people are not explicitly interested in regenerative transformations, degrowth or climate change mitigation, cultural and local practices can still provide an entry point for them. Through these common fundaments, gradual change, adaptations, and novel practices can be introduced that hopefully will lead to more regeneration instead of the current degeneration of all Planet Earth life support systems.

\section{Bibliography}

1. Archer, M.S. et al. (Eds.) (1998). Critical Realism: Essential Readings. London: Routledge.

2. Beck, U. (2009). World at Risk. Cambridge: Polity Press.

3. Bendell, J. (2018). Deep Adaptation: A Map for Navigating Climate Tragedy. University of Cumbria, IFLAS Occasional Paper 2. Published 27.07.2018. Revised 2nd Edition 27.07.2020. Retrieved March 28, 2021, from www.lifeworth.com/deepadaptation.pdf

4. Bhaskar, R. et al. (Eds.) (2010). Interdisciplinarity and Climate Change. Transforming knowledge and practice for our global future. London: Routledge.

5. Ceballos, G., Ehrlich, P.R. and Dirzo, R. (2017). Biological annihilation via the ongoing sixth mass extinction signaled by vertebrate population losses and declines. Proceedings of the National Academy of Sciences of the United States of America (PNAS), 114 (30): 6089-6096. DOI 10.1073/pnas.1704949114

6. Dasgupta, P. (2021). The Economics of Biodiversity: The Dasgupta Review. London: HM Treasury. Retrieved March 28, 2021, from www.gov.uk/government/publications/final-report-the-economics-of-biodiversity-thedasgupta-review

7. Demaria, F., Schneider, F., Sekulova, F. and Martinez-Alier, J. (2013) What is Degrowth? From an Activist Slogan to a Social Movement. Environmental Values, 22 (2): 191-215.

8. Dzenovska, D. (2012). Aizbrauksana un tuksums Latvijas laukos: starp zudusam un iespejamam nakotnem (Departure and emptiness in rural Latvia: between lost and possible futures). Riga: The University of Latvia Press. Retrieved March 28, 2021, from https://dspace.lu.Iv/dspace/bitstream/handle/7/1322/Aizbrauksana.pdf?sequence=1\&isAllowed=y

9. Fazey, I., Schäpke, N., Caniglia, G., Patterson, J., Hultman, J., van Mierlo, B., ... Wyborn, C. (2018). Ten essentials for action-oriented and second order energy transitions, transformations and climate change research. Energy Research \& Social Science, 40:54-70. DOI 10.1016/j.erss.2017.11.026

10. Fleming, D. (2016). Surviving the Future. Culture, Carnival and Capital in the Aftermath of the Market Economy. Ed. by Shaun Chamberlain. Burlington, VT: Chelsea Green Publishing.

11. Fletcher, R. and Rammelt, C. (2016). Decoupling: A Key Fantasy of the Post-2015 Sustainable Development Agenda. Globalizations, pp.450-467. DOI: 10.1080/14747731.2016.1263077

12. Gopel, M. (2016). The Great Mindshift. How a New Economic Paradigm and Sustainability Transformations go Hand in Hand. Springer Open. Retrieved March 28, 2021, from https://link.springer.com/content/pdf/10.1007\%2F978-3-319-43766-8.pdf

13. Henfrey, T.W. (2018). Designing for resilience: permaculture as a transdisciplinary methodology in applied resilience research. Ecology and Society, 23(2): 33. DOI 10.5751/ES-09916-230233 
14. Holmgren, D. (2002). Permaculture: Principles and Pathways beyond Sustainability. Victoria, Australia: Holmgren Design Services.

15. IPBES (2019). Summary for policymakers of the global assessment report on biodiversity and ecosystem services of the Intergovernmental Science-Policy Platform on Biodiversity and Ecosystem Services. IPBES secretariat, Bonn, Germany. Retrieved March 28, 2021, from https://www.ipbes.net/global-assessment-reportbiodiversity-ecosystem-services

16. IPCC (2018). Global Warming of $1.5^{\circ} \mathrm{C}$. An IPCC Special Report on the impacts of global warming of $1.5^{\circ} \mathrm{C}$ above pre-industrial levels and related global greenhouse gas emission pathways, in the context of strengthening the global response to the threat of climate change, sustainable development, and efforts to eradicate poverty. Retrieved March 28, 2021, from www.ipcc.ch/report/sr15/

17. IPCC (2019). Summary for Policymakers. In: Climate Change and Land: an IPCC special report on climate change, desertification, land degradation, sustainable land management, food security, and greenhouse gas fluxes in terrestrial ecosystems. Retrieved March 28, 2021, from https://www.ipcc.ch/srccl/

18. Keller, D.R. (Ed.) (2010). Environmental Ethics: The Big Questions. Oxford: Wiley-Blackwell.

19. Kindon, S., Pain, R. and Kesby, M. (Eds.) (2007). Participatory Action Research Approaches and Methods. Connecting people, participation and place. London: Routledge.

20. Lyle, J. T. (1994). Regenerative Design for Sustainable Development. New York: John Wiley \& Sons.

21. Massey, D. 2005. For Space. London: SAGE Publications.

22. Meadows, D.H., Meadows, D., Randers, J. and Behrens III, W.W. (1972). The Limits to Growth. A report to the Club of Rome. New York: Universe Books.

23. Mollison, B., Holmgren, D. (1978). Permaculture One: A Perennial Agriculture for Human Settlements. Melbourne, Australia: Transworld Publishers.

24. Mollison, B. and Slay, R.M. (1991). Introduction to Permaculture. Tasmania: Tagari Publications.

25. Parrique, T., Barth, J., Briens, F., Kerschner, C., Kraus-Polk, A., Kuokkanen, A. and Spangenberg J.H. (2019). Decoupling debunked: Evidence and arguments against green growth as a sole strategy for sustainability. European Environmental Bureau. Retrieved March 28, 2021, from https://eeb.org/library/decoupling-debunked/

26. Perkins, R. (2016). Making Small Farms Work. Richard Perkins.

27. Perkins, R. (2019). Regenerative Agriculture. A Practical Whole Systems Guide to Making Small Farms Work. Richard Perkins.

28. Pickett, K. and Wilkinson, R. (2009). The Spirit Level. Why Greater Equality Makes Societies Stronger. London: Bloomsbury Press.

29. Polanyi, K. 1944. The Great Transformation. The political and economic origins of our time. New York: Farrar \& Rinehart.

30. Ripple, W.J., Wolf, C., Newsome, T.M., Galetti, M., Alamgir, M., Crist, E., Mahmoud, M.I. Laurance, W.F., 15,364 scientist signatories from 184 countries (2017). World Scientists' Warning to Humanity: A Second Notice. BioScience, 67(12): 1026-1028. DOI 10.1093/biosci/bix125

31. Sansonetti, P.J. (2020). COVID-19, chronicle of an expected pandemic. EMBO Mol Med, 12: e12463. DOI: $10.15252 / \mathrm{emmm} .202012463$

32. Sayer, A. 2000. Realism and Social Science. London: Sage.

33. Schumacher, E. F. 1973. Small is Beautiful. London: Blond \& Briggs Ltd.

34.Spash, C.L. (2012). Green Economy, Red Herring. Environmental Values, 21(2): 95-99.

35. Spash, C.L. (2020). 'The economy' as if people mattered: revisiting critiques of economic growth in a time of crisis. Globalizations. DOI: 10.1080/14747731.2020.1761612

36. Steffen, W., Richardson, K., Rockström, J., Cornell, S.E., Fetzer, I., Bennett, E.M., ..., Sörlin, S. (2015a). Planetary boundaries: Guiding human development on a changing planet. Science, 342(6223).

37. Steffen, W., Broadgate, W., Deutsch, L., Gaffney, O. and Ludwig, C. (2015b). The trajectory of the Anthropocene: The Great Acceleration. Anthropocene Review, 2(1): 81-98.

38. Wright, E.O. (2010). Envisioning Real Utopias. London: Verso Books. 